\title{
Unplanned Municipal Solid Waste Dumps and Their Impact on Water Quality - A Case Study from Visakhapatnam, Andhra Pradesh, South India.
}

\author{
M.R.S.Sampath kumar and G.swathi \\ Department of Geophysics, Andhra University, Visakhapatnam, Andhra Pradesh.
}

\begin{abstract}
Ground water can be polluted in numerous ways in spite of the protective mantle which nature has provided. Liquid pollutants can originate, from waste water stabilization ponds, sludge lagoons, barhyard runoff. Septic tank leaching fields or seepage pits. Pollutants can also originate from the leachates of decomposing solid wastes as in the case of open dumps, sanitary landfills. Sanitary landfill is a method of disposing of surface on land without creative nuisances or hazards to public health or safety, by utilizing the principle, of engineering to confine the refuse to the smallest practical area to reduce it to smallest practical volume, and to cover it with a layer of earth at the conclusion of each day's operation.

Some of the most useful studies in recent years on landfill site selection and evaluation from the standpoint of practical applicability of the information has been conducted. In the present paper the impact on the quality of water in the surrounding wells of the dumpsite has been outlined. The case history is from a poshest locality in Visakhapatnam, a port city in Andhra Pradesh. Here the site selection made by the Metro authorities is unplanned and consequences unexpected the role of climate, hydrologic and geologic factors strongly influence the production and spread of contaminants from landfill sites.

Detailed hydro chemical studies and parameters which influence and effects the surrounding environment has been discussed. A case history of Visakhapatnam city is mentioned and explained the extent of time span required to bring the quality of water to normal state has been discussed. The paper deals with the Ethical values of the administration in selecting the sites at the centre of the human settlements and the post health hazards are discussed. Scientific procedures for better site selection are advised. Extensive extension studies are in progress targeting all the major cities in India.
\end{abstract}

Keywords: Groundwater, Solid waste, leachate, hydro chemical studies, Visakhapatnam.

\section{Introduction}

One of the most pressing problems facing metropolitan areas of not only India but also World today is the problem of disposal of solid waste materials. Major cities are struggling to keep up with the removal and burial of the city's waste. In the future, recycling of waste will undoubtedly solve much of the disposal problem, but in the mean time, toxic materials, as well as common urban waste, create a potential threat to the health of vast metropolitan complexes. Waste material must be placed in the ground in such a manner to preclude contamination of groundwater and surface water supplies by its fluid leachate which carries decomposition products.

The landfill method is now, and will be for some time, the principal method for disposal of solid waste in the United States. In the past landfill sites were selected primarily on the basis of economic land availability. Numerous investigations over the last several decades ([1,2]for a summary of these investigations) produced concern and widespread recognition that landfills represent a possible Source of ground-water contamination. These studies also revealed several important facts regarding leachate production and migration from landfill sites. (1) Landfills invariably produce a mobile liquid leachate from the infiltration of precipitation or from saturation of the refuse placed below the water table. (2) The leachate is extremely rich in dissolved materials (organic and inorganic) taken into solution from the refuse. (3) The leachate eventually becomes part of the hydrologic flow system and may be an Important potential source of ground-water contamination. (4) The degree of protection offered to the ground-water resource is largely a function of each local hydrogeologic environment. (5) The dissolved materials in leachate are attenuated as they move through earth materials principally by dilution, dispersion, adsorption, ion exchange, oxidation, and filtration.

Proper selection, design, and operation of landfill sites can minimize and/or localize the ground-water contamination potential through management of the generated leachate $[3,4,5]$. The leachate can be renovated or attenuated (1) under natural conditions as it moves through the underlying earth materials (2) by collection and treatment of the leachate, or (3) by a combination collection and treatment-natural attenuation system.

The majority of landfill sites in operation today depend totally, or in part, upon natural attenuation to control the generated leachate. It therefore becomes important to determine favorable hydrogeologic conditions 
for natural leachate attenuation. Research conducted to date has concentrated almost exclusively on leachate movement and attenuation within the ground-water flow system. This research has shown that leachate will be attenuated by natural processes in that system [3]. Little direct evidence is available, however, concerning changes in leachate concentrations within the unsaturated earth materials beneath landfill sites [6].

Additional information concerning the physical and chemical interactions between leachate and the unsaturated earth materials is needed in order to determine which hydrogeologic characteristics of landfill sites are favorable for minimizing the potential for ground-water contamination. Such information is also pertinent in determining the optimum site location requirements for the land disposal of solid wastes.

\section{Materials And Methods}

The ground water quality and its impact have been studied for fifteen years. The area shown is a 13 acres area in a posh locality (M.V.P. Colony), Visakhapatnam, Andhra Pradesh, wherein the Municipal Administration started accumulating the city municipal solid waste in the vacant elevated area. This is used as a source material to produce electricity, from solid waste up to 1 megawatt, shown in the Fig1.

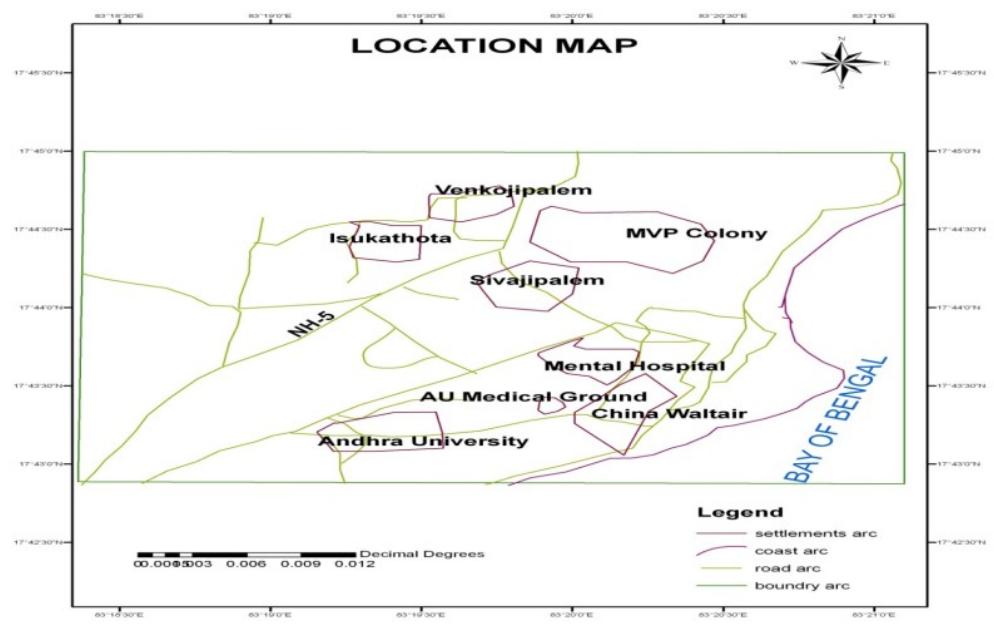

Fig1: Location Map of the study area

During the accumulation process for 5 years (1992-1997), intense rainfall in the area, decomposed the material. The pollutants from the dump in the form of leachate effected badly the urban colony around it. Health hazards increased day by day and uproar from residents forced the authorities to stop dumping in the area and it was converted in to a beautiful recreation park. This can be viewed in the photographs clearly shown in Fig2. The area is surrounded by the residential plots and flats

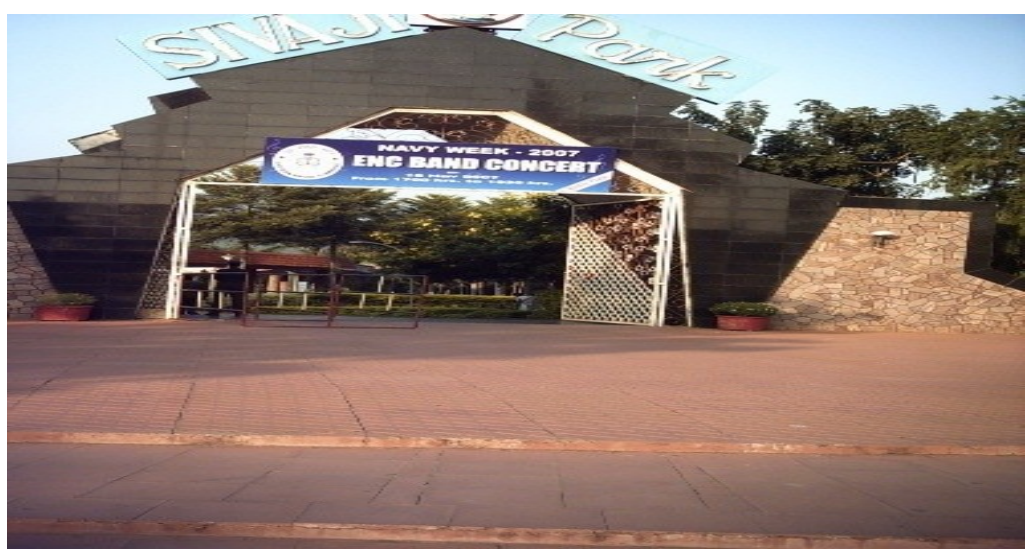




\section{Inside the pork}

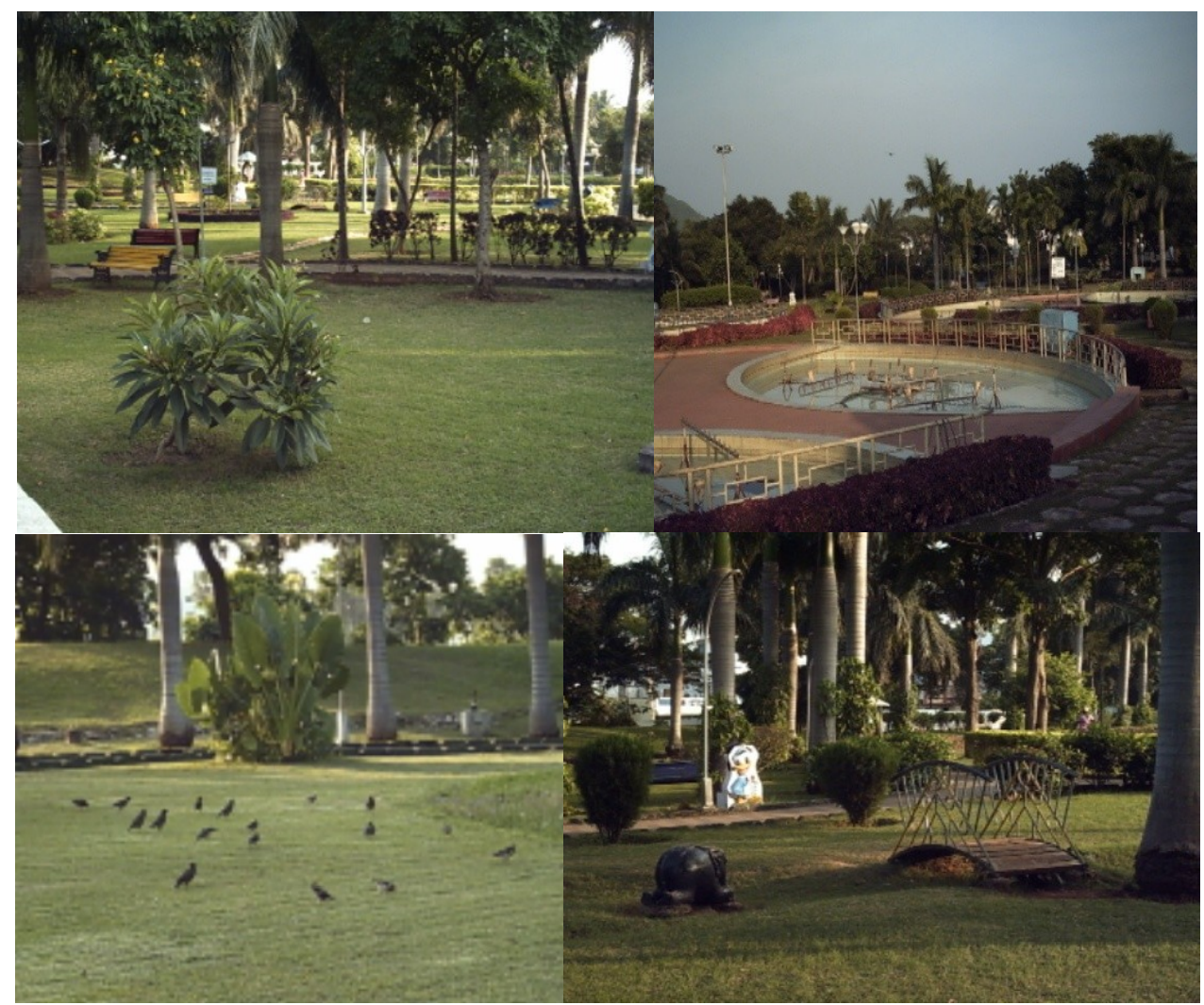

\section{Sample Collection}

Water samples have been collected around the dump. In the initial years when the severity is more, the sampling was made monthly. Later after five years the sampling was made during pre monsoon and post monsoon till today. All the major ion concentrations were analyzed using the standard methods [7]. Electrical conductivity recorded insitu. Estimation of Carbon dioxide has been made in the laboratory. Its chemistry for major ions and physical parameters were estimated and it was compared with past data.

\section{Results And Discussions}

Standard wet analysis has been carried out for Chloride, Bicarbonate, Calcium, Magnesium, Sulphate elements. Sodium and Potassium was analyzed by Flame Photometer. Carbon dioxide was analyzed Titrimetrically. The results are shown in fig 3,4. We can observe that the table, we can understand that the groundwater's in that area .Hydro chemical status of the area after fifteen years. And to show how, the unplanned dumping leads to problems, and how much time span it takes to restore the status.

Chemical characteristics of the sample water were analyzed, the $\mathrm{pH}$ of the water ranges from 7.5- 8.9, and the $\mathrm{pH}$ remain relatively within the allowable $\mathrm{WHO}$ range of $7.0-8.5$.

Free Carbon dioxide in excess of 20ppm will attack Iron; Steel and Concrete rapidly. The range of Carbon dioxide is around $300 \mathrm{ppm}$ initially and presently is $100 \mathrm{ppm}$.

The conductivity of the water samples ranges from $1000-4000 \mu / \mathrm{cm}$ for the all the samples in the sampling seasons, this values exceeded the WHO and allowable standard is $440 \mu / \mathrm{cm}$, the increase in the levels may be due to effluent from different waste.

The total dissolve solid ranged from $640-2560 \mathrm{mg} / \mathrm{l}$, which fall the maximum permissible limit is 500 $\mathrm{mg} / \mathrm{l}$. Therefore wells with high TDS will be a problem during treatment as it may cause filter clogging. For calcium the ranges were $200-800 \mathrm{mg} / \mathrm{l}$, which fall the maximum allowable limit of $500 \mathrm{mg} / \mathrm{l}$. The Chloride content ranges from $500-900 \mathrm{mg} / \mathrm{l}$, which fall below the maximum permissible limit of $200 \mathrm{mg} / \mathrm{l}$. 
Hardness is one of the very important properties of ground water from utility point of view particularly for domestic purposes. Hardness is caused by an excess of bivalent metallic ions (Calcium and Magnesium) in the water. From the research results it ranges from $490-1500 \mathrm{mg} / \mathrm{l}$, which are above the limit, this may be due to dissolution of polyvalent metallic ions from sedimentary rocks, seepage, and run off from soil. Excess concentrations of free carbon dioxide caused dissolution of Carbonate compounds from Soil and Rock formations. Water containing Carbonates and Bicarbonates of Calcium and Magnesium will form a scale when heated. This becomes increasingly critical in hot water heaters and water distribution systems, Chocking results. Alkalinity is caused primarily by the presence of Carbonates, Bicarbonates and Hydroxides. Bicarbonates represents the major form of Alkalinity. Highly Alkaline water are unpotable and objectionable to consumers.

\begin{tabular}{|l|l|l|l|l|}
\hline Year & $\mathrm{pH}$ & \multicolumn{1}{|c|}{$\begin{array}{c}\text { Conductivity } \\
\text { in } \\
\mu \mathrm{mhos} / \mathrm{cm}\end{array}$} & \multicolumn{1}{|c|}{$\begin{array}{c}\mathrm{Co}_{2} \\
\text { in } \\
\mathrm{ppm}\end{array}$} & TDS \\
\hline 1997 & 8.9 & $2000-4000$ & 300 & $1280-2560$ \\
\hline 2007 & 8 & $1000-1900$ & 150 & $640-1216$ \\
\hline 2013 & 7.5 & $1000-1200$ & 100 & $640-768$ \\
\hline
\end{tabular}

Fig3: Results of the water samples

\begin{tabular}{|l|l|l|l|l|l|l|}
\hline Year & $\begin{array}{l}\text { Calcium } \\
\text { In } \\
\text { ppm }\end{array}$ & $\begin{array}{l}\text { Magnesium in } \\
\text { ppm }\end{array}$ & $\begin{array}{l}\text { Sulphate } \\
\text { In } \\
\text { ppm }\end{array}$ & $\begin{array}{l}\text { Sodium } \\
\text { Potassium } \\
\text { in ppm }\end{array}$ & $\begin{array}{l}\text { Bicarbonate in } \\
\text { ppm }\end{array}$ & $\begin{array}{l}\text { Chloride } \\
\text { in } \\
\text { ppm }\end{array}$ \\
\hline 1997 & $700-800$ & $300-600$ & $200-600$ & $300-500$ & $1200-2000$ & $800-900$ \\
\hline 2007 & $200-700$ & $290-500$ & $35-70$ & $200-300$ & $900-1600$ & $500-900$ \\
\hline 2013 & $200-700$ & $290-500$ & $20-35$ & $200-300$ & $900-1600$ & $500-900$ \\
\hline
\end{tabular}

Fig4: Results of the water samples

The plan to dump average 100 ton of solid waste daily which is to produce electricity.With this tonnage for five years one can assume the tonnage of refuse has been dumped in an residential area. This dump enhanced the diffusion of Carbon dioxide by rainfall into the water percolating to the receiving water. Based on an average vertical velocity for Carbon dioxide movement of $0.22 \mathrm{ft} / \mathrm{day}$ in soil an overall depth to ground water of $200 \mathrm{ft}$. Carbon dioxide would require 2.5 years to reach ground water. This was boosted by rainfall in the area. It has reduced to 1year from 2.5 years for carbon dioxide to reach the water table.

Causes for high Hardness, Alkalinity in turn increases primarily as a result of carbon dioxide. These resulted health hazards of skin diseases, itching problems boosted. This lead the uproar of the public to stop dumping in the area.

\section{Conclusions}

The analysis was carried out during several years, it was observed that the there is high level of contamination on the ground water around the solid waste dump site. It is recommended that effective disposal mechanism of household in dumping sites in particular.

Predominant materials leached from refuse are chloride, sulphate, potassium, sodium and calcium. Production of gas depends on temperature, moisture content, garbage content, aeration. Leachate impairment or groundwater causes temporary increase in organic material (as published evidences) and permanent increase in ionic concentrations, resulting increase in TDS, Total hardness, Chloride, Sulphates, this lasts for several years(as in table). Carbon dioxide effects on ground water increases hardness, increases bicarbonate. Corrosive property imparted to waters and choking of public water system results. Site selection plays an important role both scientific and in social problems.

Hence sites should be selected at utmost care consulting the relevant agencies to minimize the posteffects by the metro authorities.

\section{References}

[1] A.E.Zanoni(1972) Ground water pollution and sanitary landfills- A critical review. GroundwaterV.10,N0.1,p1-14

[2] A.E.Zanoni(1973) Potential for groundwater pollution from the land disposal of solid wastes. Chemical Rubber Company Critical Riviews in Environmental control, pp225-260.

[3] Hughes,G.M.(1967).Selection of refuse disposal sites in northeastern Illinois. Illinoise state Geological survey, Environmental Geology Notes,no.17,18pp

[4] Hughes,G.M.,R.A.Landon and R.N. Farvolden(1969) Hydrogeology of solid waste disposals sites in weef., U.S.P.H.S.Bureau of solid waste Management, Dem.Grant no.D01 -U1-00006,137pp.

[5] Landon,R.A.( 1969) Application of hydrology to the selection of refuse disposal sites. Groundwater V.7., no.6, p.9.

[6] Legrand,H.E.(1968) Monitoring of changes in quality of groundwater. Ground Water. V.6, no.3, p.14.

[7] APHA,Standard Method for the Examination of Water and Waste,1992, 18th Edition, APHA, Washington, D.C. 
[8] Shankar K, Aravindran S and Rajendran S, Advances in Applied Science Research, 2011, 2(5): 92-103

[9] Swarna Latha. P., Nageswara Rao, K., Jaganadha Rao, M. and Hari Krishna, M., 'Physico-chemical characterstics of ground water in Greater Visakhapatnam Muncipal Corporation (GVMC)', Andhra Pradesh, Indian Journal of Environmental Protection, Vol. 29, No.5: 399-406 (2009)

[10] Rajkumar, N., Subramani, T. and Elango, L., 'Ground water contamination due to municipal solid waste disposal-A GIS based study in Erode city'. International journal of Environmental Sciences Vol 1, No1:39-55 (2010)

[11] WHO, 'International standards for drinking water', World Health Organization, Geneva (1971) 